\title{
FAKTOR-FAKTOR YANG BERHUBUNGAN DENGAN POLA KONSUMSI PANGAN BALITA DI WILAYAH KERJA PUSKESMAS OEPOI KOTA KUPANG
}

\author{
${ }^{1}$ Theresia Noviayanti Bur, ${ }^{2}$ Intje Picauly, ${ }^{3}$ Rut Rosina Riwu \\ ${ }^{1-3}$ Program Studi Ilmu Kesehatan Masyarakat \\ Fakultas Kesehatan Masyarakat \\ Universitas Nusa Cendana \\ Author Adress : intjepicauly@staf.undana.ac.id
}

\begin{abstract}
ABSTRAK
$G$

izi merupakan unsur yang penting dalam pemenuhan kebutuhan nutrisi, mengingat zat gizi berfungsi menghasilkan energi, membangun dan memelihara jaringan, serta mengantar proses - proses kehidupan dalam tubuh. Kondisi gizi kurang pada balita, dimungkinkan terjadi karena interaksi dari beberapa faktor di antaranya asupan makanan yang tidak adekuat, pemberian ASI yang tidak ekslusif, penyakit infeksi yang diderita balita, persepsi ibu terkait gizi, sosial ekonomi yang rendah dan budaya. Penelitian ini dilaksanakan dengan tujuan untuk mengetahui faktor - faktor yang berhubungan dengan pola konsumsi pangan anak balita di Wilayah Kerja Puskesmas Oepoi Kota Kupang. Jenis penelitian yang dilakukan adalah penelitian observasional analitik dengan rancangan penelitiian Cross Sectional Study. Populasi dan sampel dalam penelitian ini adalah ibu yang memiliki anak balita dengan usia 12 - 59 bulan sebanyak 93 orang. Data yang terkumpul selanjutnya dianalisis menggunakan analisis univariat, bivariat (uji Chi Square)dan analisis multivariat (uji Regresi Logiztic ganda). Hasil analisis sevara bivariat dan multivariat menunjukan bahwa variabel pengetahuan gizi ibu ( $p$ Value : 0.004 $<0.05)$,Tingkat pendapatan keluarga ( $p$ Value : 0.000<0.05), dan jumlah anggota keluarga (pValue : $0.000<0.05$ ) berhubungan dengan pola konsumsi pangan balita di Wilayah Kerja Puskesmas Oepoi. Oleh karena itu disarankan agar ibu yang memepunyai anak balita bisa mengubah pola asuh kepada anaknya mulai dari pemilihan bahan makanan yang baik dan bisa memberikan jenis makanan yang bergizi bagi anaknya serta memperhatikan sanitasi dan higiene dalam menyiapkan makanan untuk anak maka diperlukan penanganan sejak dini, juga perlunya pemantauan pertumbuhan balita dengan pengukuran tinggi badan secara berkala melalui posyandu pada Wilayah Kerja Puskesmas Oepoi.
\end{abstract}

Kata kunci $\quad$ : Pola Konsumsi Pangan, Anak Balita, Pusat Kesehatan Masyarakat, Zat Gizi, Pola Asuh, Sanitasi dan Higiene, pendapatan keluarga 


\title{
FACTORS RELATED TO \\ CHILDREN'S FOOD CONSUMPTION PATTERNS IN WORKING AREAS OEPOI COMMUNITY HEALTH CENTER KUPANG CITY
}

\author{
${ }^{1}$ Theresia Noviayanti Bur, ${ }^{2}$ Intje Picauly, ${ }^{3}$ Rut Rosina Riwu \\ ${ }^{1-3}$ Public health scientific program \\ Public Health Faculty \\ Nusa Cendana University \\ Author Adress : intjepicauly@staf.undana.ac.id
}

\begin{abstract}
$N$ utrition is an important element in meeting nutritional needs, considering that nutrients function to produce energy, build and maintain tissues, and deliver life processes in the body. The condition of malnutrition in toddlers may occur due to the interaction of several factors including inadequate food intake, non-exclusive breastfeeding, infectious diseases suffered by children under five, maternal perceptions regarding nutrition, low socioeconomic and culture. This research was conducted with the aim of knowing the factors related to the food consumption patterns of children under five in the working area of the Oepoi community health center, Kupang City. This type of research is analytic observational research with a cross sectional study design. The population and sample in this study were mothers who had children under five aged 12 - 59 months as many as 93 people. The collected data were then analyzed using univariate, bivariate (Chi Square test) and multivariate analysis (multiple logistic regression tests). The results of the bivariate and multivariate analysis showed that the variable maternal nutritional knowledge ( $p$ Value: $0.004<0.05$ ), the level of family income ( $p$ Value: $0.000<0.05$ ), and the number of family members ( $p$ Value: $0.000<0.05$ ) were related to the food consumption patterns of children under five in the region. The work of the Oepoi Community Health Center. Therefore it is recommended that mothers who have children under five can change their parenting style, starting from the selection of good food ingredients and being able to provide nutritious types of food for their children as well as paying attention to sanitation and hygiene in preparing food for children, so early handling is needed, as well as the need monitoring the growth of toddlers with regular height measurements through the posyandu in the Oepoi Health Center Work Area.
\end{abstract}

Keywords : Food Consumption Patterns, Toddler Children, Community Health Centers, Nutrition, Parenting, Sanitation and Hygiene, family income 


\section{PENDAHULUAN}

Gizi merupakan unsur yang penting dalam pemenuhan kebutuhan nutrisi, membangun dan memelihara jaringan, serta mengatur proses-proses kehidupan dalam tubuh. Selain itu gizi juga berhubungan dengan perkembangan otak, kemampuan belajar dan produktivitas kerja (Waryana, 2010). Balita gizi kurang akan mengalami penurunan kekebalan tubuh terhadap invasi patogen sehingga lebih rentan terhadap kejadian infeksi (Calder, 2000). Sebaliknya, pertumbuhan yang baik dan status imunologi yang memadai akan menghasilkan tingkat kesehatan yang baik pula (Aritonang, 2007).

Anak di bawah lima tahun adalah kelompok umur yang sangat rentan terhadap berbagai penyakit infeksi dan membutuhkan zat gizi yang relatif lebih tinggi dibandingkan kelompok umur yang lain (Mulyati, 2004). UNICEF (2013) mencatat ratusan anak di dunia menderita kekurangan gizi yang artinya permasalahan ini terjadi dalam populasi yang jumlahnya sangat besar. Balita yang meninggal akibat gizi kurang dan buruk di negara berkembang pada tahun 2013 dilaporkan sebanyak 2.835.000 atau $45 \%$ dari total jumlah kematian balita (WHO, 2013). Kondisi ini dimungkinkan terjadi karena interaksi dari beberapa faktor di antaranya asupan makanan yang tidak adekuat, pemberian ASI yang tidak ekslusif, penyakit infeksi yang diderita balita, pola pengasuhan keluarga, pelayanan kesehatan, jumlah anggota keluarga, tingkat pendidikan ibu, persepsi ibu terkait gizi, sosial ekonomi yang rendah dan budaya (UNICEF, 2013). Penyebab dasar terjadinya gizi kurang pada balita adalah status ekonomi yang rendah (UNICEF, 2013). Dimana kondisi kemiskinan mempengaruhi kondisi ketahanan pangan dalam keluarga dan faktor penyebab lain yaitu rendahnya tingkat pendidikan (UNICEF, 2013).

Laporan Riskesdas (2018) terlihat bahwa prevalensi balita gizi buruk cenderung mengalami penurunan dari tahun 2007-2018 (5.4\% turun menjadi 3.9\%) sedangkan prevalensi gizi kurang cenderung meningkat dari tahun 2007 - 2018 (13.0\% menjadi 13.8\%). Untuk kejadian balita stunting (pendek dan sangat pendek) memberikan kecenderungan perubahan yang berbeda. Riskesdas (2018) juga melaporkan bahwa prevalensi balita sangat pendek cenderung menurun dari tahun 2007-2018 (18.8 menjadi 11.5) dan prevalensi balita pendek cenderung meningkat dari tahun 2007 - 2018 (18.0\% menjadi 19.3\%). Puskesmas Oepoi merupakan salah satu puskesmas dari 11 puskesmas di Kota Kupang yang memiliki angka kejadian balita gizi kurang tertinggi. Berdasarkan Profil Kesehatan Kota Kupang diketahui bahwa jumlah balita yang berada pada Bawah Garis Merah (BGM) sebesar 4,6\% terjadi penurunan menjadi 4,5\%. Berdasarkan jumlah balita yang ditimbang diketahui bahwa persentase gizi kurang sebesar 12,2\% meningkat menjadi $13 \%$ ditahun 2018. Berdasarkan uraian inilah, peneliti tertarik untuk melakukan penelitian tentang faktor-faktor yang berpengaruh terhadap pola konsumsi pangan Balita di Wilayah Kerja Puskesmas Oepoi Kota Kupang.

\section{METODE PENELITIAN}

Penelitian ini menggunakan desain penelitian cross sectional study dengan populasi dan sampel adalah ibu yang mempunyai bayi umur 6-24 bulan di Puskesmas Takari sebanyak 60 ibu pada bulan April - Juni 2019. Data dikumpulkan dengan 
mengunakan lembar kuesioner dan observasi lapangan. Setelah data terkumpul lanjut dianalisis menggunakan alat analisis univariat dan bivariat dengan rumus pembuktian hipotesis adalah uji statistic Chi-square (Sugiyono, 2007).

\section{HASIL DAN PEMBAHASAN}

\section{HASIL PENELITIAN}

\section{Profil responden berdasarkan faktor - faktor yang berhubungan dengan pola konsumsi pangan anak balita.}

Penelitian terdahulu banyak yang telah membuktikan bahwa faktor pengetahuan, Usia ibu, tingkat pendidikan formal, pekerjaan ibu, pendapatan, dan keterpaparan terhadap informasi merupakan sejumlah faktor yang dapat berpengaruh terhadap pola konsumsi pangan keluarga dan anggota keluarganya.

Tabel 1. Distribusi Persentasi Responden Berdasarkan Faktor - Faktor Yang Berhubungan Dengan Pola Konsumsi Pangan Anak Balita di Wilayah Kerja Puskesmas Oepoi Kota Kupang.

\begin{tabular}{|c|c|c|c|}
\hline No & $\begin{array}{c}\text { Indikator } \\
\text { (Variabel Independent dan Dependent) }\end{array}$ & $\mathbf{n}$ & $\%$ \\
\hline \multicolumn{4}{|c|}{ A. Umur (Thn/bulan) anak } \\
\hline 1 & $12-36$ bulan & 71 & 76,34 \\
\hline 2 & $37-59$ bulan & 22 & 23,66 \\
\hline \multicolumn{4}{|c|}{ B. Jenis Kelamin } \\
\hline 1 & Laki-laki & 48 & 51,61 \\
\hline 2 & Perempuan & 45 & 48,39 \\
\hline \multicolumn{4}{|c|}{ C. Umur Ibu Balita (Thn) } \\
\hline 1 & 16-18 tahun & 2 & 2,15 \\
\hline 2 & 19-29 tahun & 38 & 40,86 \\
\hline 3 & 30-49 tahun & 53 & 56,99 \\
\hline \multicolumn{4}{|c|}{ D. Pola Konsumsi } \\
\hline 1 & Kurang Baik & 49 & 52,7 \\
\hline 2 & Baik & 44 & 47,3 . \\
\hline \multicolumn{4}{|c|}{ E. Tingkat Pendidikan Ibu Balita } \\
\hline 1 & Tamat SD & 16 & 17,20 \\
\hline 2 & Tamat SMP & 21 & 22,59 \\
\hline 3 & Tamat SMA & 42 & 45,16 \\
\hline 4 & Tamat PT & 14 & 14,60 \\
\hline \multicolumn{4}{|c|}{ F. Pengetahuan Gizi Ibu Balita } \\
\hline 1 & Kurang & 75 & 80,6 \\
\hline 2 & Baik & 18. & 19,4 \\
\hline \multicolumn{4}{|c|}{ G. Pemberian Makanan Pendamping - ASI } \\
\hline 1 & $\mathrm{Ya}$ & 37 & 61.7 \\
\hline 2 & Tidak & 23 & 38.3 \\
\hline
\end{tabular}




\begin{tabular}{|c|c|c|c|}
\hline 1 & Ibu Tidak Bekerja & 89 & 95,7 \\
\hline 2 & Ibu Bekerja & 4 & 4,3 \\
\hline \multicolumn{4}{|c|}{ I. Tingkat Pendapatan Keluarga } \\
\hline ‘1 & Rendah & 71 & 76,3 \\
\hline 2 & Tinggi & 22 & 23,7 \\
\hline \multicolumn{4}{|c|}{ J. Jumlah Anggota Keluarga } \\
\hline 1 & Kecil & 34 & 36,6 \\
\hline 2 & Besar & 59 & 63,4 \\
\hline \multicolumn{4}{|c|}{ K. Riwayat Penyakit Infeksi } \\
\hline 1 & Ada & 33 & 35,5 \\
\hline 2 & Tidak Ada & 60 & 64,5 \\
\hline \multicolumn{4}{|c|}{ L. Riwayat Pantangan Makanan } \\
\hline 1 & Ada & 27 & 29,0 \\
\hline 2 & Tidak Ada & 66 & 71,0 \\
\hline \multicolumn{2}{|r|}{ Total } & 93 & 100 \\
\hline
\end{tabular}

abel 1 menunjukkan bahwa responden lebih banyak (76.34\%) berusia 12-36 bulan dengan jenis kelamin lebih banyak anak laki-laki. Sedangkan ibu balita, lebih banyak (56.99\%) berumur 30-49 tahun dengan tingkat pendidikan tertinggi pada kelompok lulusan SMA (45.16\%) namun sebagian besar ibu-ibu balita ini memiliki tingkat pengetahuan buruk (80.6\%). Dipihak lain ibu balita sebagian besar memiliki pekerjaan sebagai ibu rumah tangga (95.7\%) dengan tingkat pendapatan yang rendah $(76.3 \%)$ dan harus menghidupi keluarga anggota keluarga lebih dari empat orang (63.4\%).

Profil keluarga balita sampel menunjukkan bahwa sebagian besarnya (52.7\%) mempunyai pola konsumsi yang kurang baik. Namun, sebagian besar $(61.7 \%)$ anaknya sudah mendapat tindakan pemberian makanan pendamping ASI tanpa adanya makanan pantangan (71\%) dan tidak memiliki riwayat penyakit infeksi $(64.5 \%)$.

\section{Faktor-Faktor yang berhubungan dengan Pola Konsumsi Pangan}

Pengetahuan seseorang biasanya diperoleh dari pengalaman yang berasal dari berbagai sumber, misalnya media massa, media elektronik, buku petunjuk, petugas kesehatan, media poster, kerabat dekat dan sebagainya (Notoatmodjo, 2010). Hasil analisis pada Tabel 2 menunjukkan bahwa ada hubungan antara pengetahuan ibu dengan pemberian MP-ASI (pValue : 0.004<0.05). Dimana, ibu balita sebagian besar $(60 \%)$ mempunyai pengetahuan gizi yang buruk mempunyai pola konsumsi yang kurang baik. Namun, dipihak lain banyak anak balita yang tidak mempunyai riwayat penyakit infeksi justru mempunyai pola konsumsi yang kurang baik. Hal ini terbukti dari hasil analisis yang menunjukkan bahwa faktor riwayat penyakit infeksi tidak berhubungan dengan penerapan pola konsumsi yang baik. Hasil yang sama juga pada faktor riwayat makanan pantangan (Tabel2). Dimana, hasil analisis menunjukkan bahwa tidak ada hubungan antara faktor riwayat makanan pantangan dikarenakan sebagian besar (53.03\%) anak balita tidak mempunyai riwayat makanan pantangan namun penerapan pola konsumsinya kurang baik. 
Tabel 2. Faktor-Faktor yang berhubungan dengan Pola Konsumsi Pangan di Wilayah Kerja Puskesmas Oepoi Kota Kupang

\begin{tabular}{|c|c|c|c|c|c|c|c|c|}
\hline \multirow{3}{*}{ No } & \multirow{3}{*}{ Indikator } & \multicolumn{4}{|c|}{ Pola Konsumsi Pangan } & \multirow{2}{*}{\multicolumn{2}{|c|}{ Total }} & \multirow{3}{*}{ p-value } \\
\hline & & \multicolumn{2}{|c|}{ Kurang Baik } & \multicolumn{2}{|c|}{ Baik } & & & \\
\hline & & $\mathrm{n}$ & $\%$ & $\mathrm{n}$ & $\%$ & $\mathrm{n}$ & $\%$ & \\
\hline \multicolumn{9}{|c|}{ A. Pengetahuan Gizi Ibu } \\
\hline 1. & Kurang & 45 & 60,00 & 30 & 40,00 & 75 & 100 & \multirow[t]{2}{*}{0,004} \\
\hline 2. & Baik & 4 & 22,22 & 14 & 77,78 & 18 & 100 & \\
\hline \multicolumn{9}{|c|}{ B. Pekerjaan Ibu } \\
\hline 1 & Tidak bekerja & 48 & 53,93 & 41 & 46,06 & 89 & 100 & \multirow[t]{2}{*}{0,257} \\
\hline 2 & Bekerja & 1 & 25,00 & 3 & 75,00 & 4 & 100 & \\
\hline \multicolumn{9}{|c|}{ C. Tingkat Pendapatan Keluarga } \\
\hline 1 & Rendah & 47 & 66,19 & 24 & 33.80 & 71 & 100 & \multirow[t]{2}{*}{0.000} \\
\hline 2 & Tinggi & 2 & 9,09 & 20 & 90,90 & 22 & 100 & \\
\hline \multicolumn{9}{|c|}{ D. Jumlah Anggota keluarga } \\
\hline 1 & Kecil & 28 & 42,42 & 38 & 57,57 & 59 & 100 & \multirow[t]{2}{*}{0.000} \\
\hline 2 & Besar & 21 & 77,78 & 6 & 22,22 & 34 & 100 & \\
\hline \multicolumn{9}{|c|}{ E. Riwayat Penyakit Infeksi } \\
\hline 1 & Tidak Ada & 33 & 55,00 & 27 & 45,00 & 60 & 100 & \multirow[t]{2}{*}{0.547} \\
\hline 2 & Ada & 16 & 48,48 & 17 & 51,51 & 33 & 100 & \\
\hline \multicolumn{9}{|c|}{ F. Riwayat Pantangan Makanan } \\
\hline 1 & Tidak Ada & 35 & 53,03 & 31 & 46,97 & 66 & 100 & \multirow[t]{2}{*}{0.918} \\
\hline 2 & Ada & 14 & 51,85 & 13 & 48,14 & 27 & 100 & \\
\hline
\end{tabular}

Tabel 2 menunjukkan bahwa sebagian besar (77.4\%) ibu balita yang tidak bekerja mempunyai pola konsumsi yang kurang baik dibanding ibu-ibu yang tidak bekerja namun mempunyai pola konsumsi yang baik. Hasil analisis menunjukkan bahwa tidak ada hubungan (pValue : 0.257>0.05) antara pekerjaan ibu rumah tangga dengan pola konsumsi balita. Berdasarkan tingkat pendapatan keluarga diketahui bahwa sebagian besar ibu-ibu (90.90\%) yang mempunyai pendapatan tinggi mempunyai pola konsumsi pangan yang baik dibanding ibu-ibu yang mempunyai tingkat pendapatan rendah. hasil analisis menunjukkan bahwa faktor tingkat pendapatan keluarga berhubungan (pValue : $0.000<0.05)$ dengan penerapan pola konsumsi pangan balita dirumah. Selanjutnya, hasil analisis juga menemukan bahwa besar kecilnya jumlah anggota rumah tangga berhubungan (pValue : $0.000<0.05$ ) dengan penerapan pola konsumsi pangan balita. Dimana, distribusi persentase menemukan bahwa sebagian besar $(77.78 \%)$ keluarga yang mempunyai jumlah anggota yang besar mempunyai pola konsumsi yang kurang baik.

\section{Hubungan Faktor Dominan (Tingkat Pengetahuan Gizi Ibu, Jumlah Anggota Keluarga dan Tingkat Pendapatan Keluarga) dengan Pola Konsumsi Pangan Keluarga Balita}

Variabel yang dapat dimasukkan dalam model multivariabel setelah melewati tahap seleksi bivariabel diperoleh tiga variabel yaitu tingkat pengetahuan gizi ibu, pendapatan keluarga, dan jumlah anggota keluarga. Hasil akhir analisis dapat dilihat pada Tabel 3. 
Tabel 3. Hasil Analisis Regresi Logistik Berganda (Variables in The Equation)

\begin{tabular}{|c|c|c|c|c|c|}
\hline \multirow[b]{2}{*}{ Variabel } & \multirow[b]{2}{*}{$\boldsymbol{B}$} & \multirow[b]{2}{*}{ Sig. } & \multirow[b]{2}{*}{$\operatorname{Exp}(B)$} & \multicolumn{2}{|c|}{ 95\% C.I.for $\mathrm{EXP}(B)$} \\
\hline & & & & $\begin{array}{c}\text { Lowe } \\
\mathbf{r}\end{array}$ & Upper \\
\hline $\begin{array}{c}\text { Tingkat } \\
\text { pengetahuan gizi ibu }\end{array}$ & 2.806 & .001 & 16.541 & 2.932 & 93.314 \\
\hline Pendapatan keluarga & 2.949 & .001 & 19.084 & 3.346 & 108.853 \\
\hline Jumlah anggota keluarga & 2.444 & .001 & 11.514 & 2.730 & 48.563 \\
\hline Constant & -11.003 & .000 & .000 & & \\
\hline
\end{tabular}

Tabel 3 menunjukkan bahwa variabel-variabel independen yang berisiko secara statistik terhadap variabel dependen yaitu pola konsumsi ( $p$ value $\leq 0,05$ ) adalah tingkat pengetahuan gizi ibu, pendapatan keluarga, dan jumlah anggota keluarga. Urutan pengaruh atau besar risiko dari masing-masing faktor dengan berpatokan pada nilai OR (Exp B) adalah pendapatan keluarga berisiko sebanyak 19.084, tingkat pengetahuan gizi ibu 16.541 dan jumlah anggota keluarga 11.514 dalam mebentuk pola konsumsi balita. Hasil analisis secara bersamaan menunjukkan bahwa anak balita dengan keluarga yang memiliki pendapatan keluarga rendah, tingkat pengetahuan gizi ibu yang kurang serta banyaknya jumlah anggota keluarga akan memiliki risiko 94\% penerapan pola konsumsi pangan yang kurang baik.

\section{PEMBAHASAN}

Pengetahuan gizi yang baik akan menyebabkan seseorang mampu untuk menyusun menu makanan yang baik untuk dikonsumsi. Semakin bertambah pengetahuan ibu maka akan semakin mengerti jenis dan jumlah makanan untuk dikonsumsi seluruh anggota keluarga termasuk pada anak balita. Hasil analisis menunjukkan bahwa ada hubungan tingkat pengetahuan gizi dengan pola konsumsi pangan balita. Hal ini disebabkan karena proporsi ibu dengan pengetahuan gizi kurang cenderung memiliki tingkat pola konsumsi pangan balita yang kurang baik dibandingkan dengan yang memiliki pola konsumsi pangan yang baik. Pola makan anak balita yang baik ditunjang oleh pengetahuan gizi ibu yang baik. Tingkat pengetahuan gizi ibu yang baik akan mendorong ibu untuk menentukan makanan yang memiliki kandungan gizi yang dibutuhkan anak. Semakin meningkatnya pengetahuan yang dimiliki ibu maka semakin tinggi pula kemampuan ibu dalam memilih dan merencananakan makanan dengan ragam dan kombinasi yang tepat sesuai dengan syarat-syarat gizi yang dianjurkan. Penelitian ini sejalan dengan penelitian dari Syukriawati (2011) bahwa semakin tinggi pengetahuan ibu tentang gizi dan kesehatan maka penilaian terhadap makanan semakin baik, sedangkan pada keluarga yang pengetahuannya rendah seringkali anak makan dengan tidak memenuhi kebutuhan gizi.

Ibu yang sudah mempunyai pekerjaan kurang memberikan perhatian penuh terhadap anak balitanya karena kesibukan dan beban kerja yang ditanggungnya sehingga menyebabkan kurangnya perhatian ibu dalam menyiapkan hidangan yang sesuai untuk balitanya (Anisa, 2012). Hasil analisis menunjukkan bahwa tidak ada hubungan antara pekerjaan ibu dengan pola konsumsi pangan balita. Ibu yang tidak bekerja dalam keluarga 
dapat mempengaruhi asupan gizi balita karena ibu berperan sebagai pengasuh dan pengatur konsumsi makanan anggota keluarga. Ibu yang bekerja tidak memiliki waktu yang cukup untuk mengasuh dan merawat anaknya sehingga anaknya dapat menderita gizi kurang (Handayani, 2013).

Perubahan pendapatan dapat mempengaruhi konsumsi pangan pada balita. Pendapatan yang meningkat berarti memperbesar peluang untuk membeli pangan dengan kualitas dan kuantitas yang lebih baik dan sebaliknya penurunan pendapatan akan menyebabkan penurunan dalam hal kualitas dan penurunan kuantitas pangan yang dibeli (Baliwati dkk, 2004). Yohanes, (2016) juga menyatakan bahwa pendapatan yang tinggi memungkinkan keluarga untuk memilih bahan makanan yang bergizi tinggi dalam memenuhi kebutuhan pangan keluarga termasuk kebutuhan anak balita. Hasil analisis menunjukkan bahwa ada pengaruh tingkat pendapatan keluarga terhadap pola konsumsi pangan balita. Hal ini disebabkan karena proporsi keluarga dengan pendapatan keluarga rendah cenderung memiliki tingkat pola konsumsi pangan balita yang kurang baik dibandingkan dengan yang memiliki pola konsumsi pangan baik. Hal ini dapat dibuktikan oleh data yang dikumpulkan melalui wawancara diketahui bahwa pendapatan keluarga di wilayah kerja Puskesmas Oepoi termasuk kategori rendah.

Jumlah anggota keluarga adalah faktor yang memiliki kaitan erat dengan banyaknya individu yang dipenuhi kebutuhan gizinya. Kualitas dan kuantitas makanan yang bergizi yang harus disediakan keluarga akan semakin meningkat dan bervariasi dengan komposisi rumah tangga. Apabila pembagian untuk masing- masing anggota keluarga tidak baik, maka akan terjadi persaingan dalam konsumsi makanan sehingga balita akan mudah tersisih dan memperoleh bagian yang kecil dan tidak dapat memenuhi kebutuhan tubuhnya untuk tumbuh dan berkembang. Hasil analisis menunjukkan bahwa ada pengaruh jumlah anggota keluarga terhadappola konsumsi pangan balita. Hal ini disebabkan karena proporsi jumlah anggota yang kecil cenderung memiliki tingkat pola konsumsi pangan balita yang baik dibandingkan dengan yang memiliki pola konsumsi pangan kurang baik. Hal ini dapat dibuktikan oleh data yang dikumpulkan melalui wawancara diketahui bahwa jumlah anggota keluarga di wilayah kerja Puskesmas Oepoi lebih banyak yang memiliki jumlah anggota keluarga besar.

Hal ini sesuai dengan pendapat Suhardjo (2010) bahwa lebih mudah untuk memenuhi kebutuhan gizi apabila anggota yang harus diberi makanan jumlahnya sedikit. Berdasarkan hasil penelitian peneliti, banyak responden dengan jumlah anggota keluarganya besar. Menurut peneliti, keadaan seperti ini menyebabkan kurang terpenuhinya kebutuhan nutrisi keluarga dikarenakan jumlah pangan yang ada dalam rumah tangga harus dibagi dengan banyaknya anggota keluarga, apalagi dalam satu rumah lebih banyak jumlah orang dewasa dari pada balita, sehingga pangan yang ada didahulukan untuk orang yang lebih tua atau yang dihormati di dalam rumah tersebut, hal ini dapat mengakibatkan kurangnya asupan nutrisi bagi balita sehingga berdampak pada permasalahan gizi.

Analisis secara simultan faktor-faktor yang berpengaruh terhadap pola konsumsi anak balita di wilayah kerja Puskesmas Oepoi Kota Kupang diketahui bahwa anak balita yang memiliki tingkat pendapatan keluarga rendah berisiko 19,084 kali memiliki pola 
konsumsi pangan yang kurang baik. Anak balita dengan keluarga yang memiliki tingkat pengetahuan gizi ibu kurang berisiko 16,541 kali memiliki pola konsumsi pangan yang kurang baik. Jumlah anggota keluarga yang besar berisiko 11,514 kali memiliki pola konsumsi pangan balita yang kurang baik. Faktor dominan sebagai risiko utama pola konsumsi pangan anak balita di wilayah kerja Puskesmas Oepoi Kota Kupang adalah tingkat pendapatan keluarga, tingkat pengetahuan gizi ibu dan jumlah anggota keluarga. Anak balita pada masa ini sering mengalami kesulitan makan, apabila kebutuhan nutrisi tidak ditangani dengan baik maka akan mudah terjadi kekurangan gizi (Muaris, 2006). Penyebab dasar terjadinya gizi kurang pada balita adalah status ekonomi keluarga yang rendah (UNICEF, 2013). Kondisi kemiskinan mempengaruhi kondisi ketahanan pangan dalam keluarga (Almatsier, 2009). Penyebab dasar lain yang berkontribusi dalam terjadinya masalah gizi kurang pada balita adalah pendidikan (UNICEF, 2013).

\section{PENUTUP}

\section{SIMPULAN}

Hasil penelitian tentang faktor-faktor yang berpengaruh terhadap pola konsumsi pangan balita di wilayah kerja Puskesmas Oepoi Kota Kupang, dari beberapa variabel dapat disimpulkan bahwa:

1. Ada pengaruh tingkat pengetahuan gizi ibu terhadap pola konsumsi pangan balita di wilayah kerja Puskesmas Oepoi Kota Kupang.

2. Tidak ada pengaruh pekerjaan ibu terhadap pola konsumsi pangan balita di wilayah kerja Puskesmas Oepoi Kota Kupang.

3. Ada pengaruh pendapatan keluarga terhadap pola konsumsi pangan balita di wilayah kerja Puskesmas Oepoi Kota Kupang.

4. Ada pengaruh jumlah anggota keluarga terhadap pola konsumsi pangan balita di wilayah kerja Puskesmas Oepoi Kota Kupang.

5. Tidak ada pengaruh riwayat penyakit infeksi terhadap pola konsumsi pangan balita di wilayah kerja Puskesmas Oepoi Kota Kupang.

6. Tidak ada pengaruh riwayat pantangan makan terhadap pola konsumsi pangan balita di wilayah kerja Puskesmas Oepoi Kota Kupang.

\section{DAFTAR PUSTAKA}

Almatsier, S. (2009). Gambaran Karateristik Ibu yang Mempunyai Balita Gizi Kurang di Puskesmas Kokap 2 Kabupaten Kulonprogo Yogyakarta. KTI. 1-32 Almatsier, S. (2009). Prinsip dasar ilmu gizi (edisi ketujuh). Jakarta: Gramedia Pustaka Utama.

Aritonang, I. (2007). Pemantauan Pertmbuhan Balita. Yogyakarta.

Calder Philip C. (2000). Hubungan Status Gizi terhadap Terjadinya Infeksi Saluran Pernapasan Akut (Ispa) pada Balita di Puskesmas Pajang Surakarta. In Suman Yus Mei Hadiana. Jurnal. 1-13. 
Handayani, 2013. Faktor-faktor yang Berhubungan dengan Status Gizi Balita di Desa Pemenang Timur, Kecamatan Lombok Barat, Nusa Tenggara Barat. Yogyakarta. UGM. Skripsi.

Mulyati T., Prawirohartono. (2004). Hubungan Status Gizi terhadap Terjadinya Infeksi Saluran Pernapasan Akut (Ispa) pada Balita di Puskesmas Pajang Surakarta. In Suman Yus Mei Hadiana. Jurnal. 1-13.

Suhardjo. (2003). Berbagai Cara Pendidikan Gizi. Jakarta: Bumi Aksara Supariasa I,D,N., Bakri B., dan Fajar B., (2001). Penilaian Status Gizi.Jakarta:EGC.

UNICEF. (2013). Improving Child Nutrition. New York: Division Of Communication UNICEF

Waryana, (2010). Hubungan Status Gizi terhadap Terjadinya Infeksi Saluran Pernapasan Akut (Ispa) pada Balita di Puskesmas Pajang Surakarta.In Suman Yus Mei Hadiana. Jurnal. 1-13.

WHO. (2013). Faktor Risiko Kejadian Gizi Buruk dan Kurang di Puskesmas Kori Kecamatan Kodi Utara Kabupaten Sumba Barat Daya. Skripsi.

Berg, Alan. 1986. Peranan Gizi dalam Pembangunan Nasional. Rajawali. Jakarta.

Riset Kesehatan Dasar (Riskesdas). 2018. Badan Penelitian dan Pengembangan Kesehatan Kementerian RI tahun 2018. http://www.depkes. go.id/resources/download/infoterkini/materi_rakorpop_2018/Hasil\%20Riskesdas \%202018.pdf - Diakses Agustus 2018.

Suhardjo.2010. Pemberian Makanan Pada Bayi dan Anak. Yogyakarta : Kanisius

Sugiyono. 2007. Metode Penelitian Kualitatif Kuantitatif dan R\&D. Bandung : Alfabeta 